\title{
THE NETWORK OF ULAMA AND ITS ROLE IN THE DEVELOPMENT OF ISLAM IN NORTH SUMATRA
}

\author{
Azhari Akmal Tarigan \\ UIN Sumatera Utara Medan, Indonesia \\ E-mail: azhariakmaltarigan@uinsu.ac.id \\ Nurhayati \\ UIN Sumatera Utara Medan, Indonesia \\ E-mail: nurhayati@uinsu.ac.id \\ Muhammad Syukri Albani Nasution \\ UIN Sumatera Utara Medan, Indonesia \\ E-mail: syukri_albani@yahoo.co.id
}

\begin{abstract}
Islam in North Sumatra has not become a serious concern in the scholarship of Islam in Indonesia. Two assumptions are underlying the causes of this fact. First, Islam in North Sumatra is perceived as a continuation of Aceh Islam. Secondly, North Sumatra is often identified as Christian territory. This study aims to examine the communication between ulama in developing Islam in North Sumatra. It will look at the role of educational institutions as well as the influence of ulama in calling for social changes. The method used in this research is descriptive qualitative, which aims to understand social problems, events, the role of interaction, and community groups. The qualitative approach is used by focusing on the social conditions surrounding the existence of the ulama which became the basis in compiling the historical events of the ulama network in the development of Islam in North Sumatra in the 20th century. This article argues that; first, the scientific network among the ulama in North Sumatra contributes to the emergence of the Islamic educational system. Secondly, the role of Musthafawiyah boarding school and Maktab Islamiyah Tapanuli is very important in developing an Islamic understanding of the communities. Third, the ulama continue to maintain Islamic teaching as a source of moral guidance to all problems of social change.
\end{abstract}

Keywords: Ulama network; Islam; North Sumatra, Musthafawiyah; Maktab Islam Tapanuli.

Article history: Received: 11 June 2020; Revised: 12 August 2020; Accapted: 21 August 2020; Available online: 01 September 2020. 


\section{How to cite this article:}

Nurhayati, Azhari Akmal Tarigan, and Muhammad Syukri Albani Nasution. "The Network of Ulama and Its Role in The Development of Islam in North Sumatra". Religio: Jurnal Studi Agama-agama 10, no. 2 (2020): 209-226. https://doi.org/10.15642/religio.v10i2.1516

\section{Introduction}

Islam in Southeast Asia has been considered as 'bad', 'syncretic', and 'nominal' by some scholars. ${ }^{1}$ Van Leur, for example, argues that Islam is only a small layer of the local culture that has not brought any development in the economics and social sectors. Yet, another scholar such as Najib al-Attas ${ }^{2}$ rejects such ideas. According to Najib, Islam has brought a socio-cultural and traditional spiritual change to the Malay-Indonesian community. The arrival of Islam has brought enlightenment for Southeast Asia since it strongly supports the intellectualism that cannot be seen in the Hindu-Buddhist era. The shift of Malay in Indonesia from the culture and religion of HinduBuddha to Islam had changed the view of the Western which was originally influenced by Greek mythology to the world of reason and enlightenment. $^{3}$

Despite there is a strong argument on the significant influence of Islam on the development of Indonesian society as discussed by Najib, we see that Islamic account is absent in North Sumatra. The mainstream discussion on Islam in Indonesia tends to be centralized to the experience of Muslims in Java and the western part of Sumatra. Usually, the historical trajectory of Islam in Indonesia begins with the Muslim figures such as Nur Al-Din Al-Raniri and Abd Rauf Al-Sinkili

\footnotetext{
${ }^{1}$ Faizal Amin and Rifki Abror Ananda, "Kedatangan dan Penyebaran Islam di Asia Tenggara Telaah Teoritik tentang Proses Islamisasi Nusantara," in Jurnal Analisis: Jurnal Studi Keislaman, Vol. 18, No. 2 (2018). Read more about syncretic Islam in: 1. Harry J. Benda, Bulan Sabit dan Matahari Terbit (Jakarta: Pustaka Jaya, 1980); 2. Clifford Geertz, Abangan, Santri dan Priyayi dalam Masyarakat Jawa (Jakarta: Pustaka Jaya, 1981); 3. W. F. Wertheim, Indonesian Society in Transition (Bandung: Sumur, 1956); 4. Robert Jay, Santri, Abangan, Religious Schism in Rural Java (Harvard: Harvard University Press, 1957); 5. Howard M. Fiderspiel, Persatuan Islam, Pembaharuan Islam Indonesia Abad XIX (Yogyakarta: Gadjah Mada University Press, 1996).

2 J. C. Van Leur, Indonesia: Trade and Society (Den Hagg: Van Hoeve, 1955), 169.

3 J. C. Van Leur, Indonesia: Trade and Society, 6.
} 
in Aceh, ${ }^{4}$ Walisongo (the nine saints) and Sheikh Siti Jenar in Java, and Sheikh Yusuf Al-Makassari in East Indonesia. ${ }^{5}$

A scholarly account on Islam in North Sumatra perhaps only highlighted by Musyrifah who argues that there were Arab colonies in Barus since 674 AD. ${ }^{6}$ However, her theory is refuted by Taufiq Abdullah, stating that there was no evidence of Muslim merchants arrived in Barus. This implies that there is a possibility of Islam in North Sumatra which has not been examined. Questions concerning how the actual role of Barus in the development of Islam in Sumatra and the existence of North Sumatran students who learned Islam to Mecca which took place between the $18^{\text {th }}$ to $19^{\text {th }}$ century are yet to explore. It may also relevant to question the influence of the Middle East Muslim to Islam in North Sumatra. As Azra argues, the dynamic of Islam in Indonesia is never detached from the dynamic of the development of Islam in other areas, particularly the Middle East. Since the arrival of Islam, many things happen such as the process of Islamization, the emergence of a network of ulama, the rise of Islamic modernism, and the growth of Indonesian nationalism. ${ }^{7}$ Bearing this in mind, we feel that it is important to explore the role of Muslim scholars and ulama in North Sumatra to the development of Islam in Indonesia.

At least, two important Islamic centers in Sumatra are interesting to discuss. First, Mushtafawiyyah Boarding School, located in Purba Baru, Mandailing Natal. This is perhaps the largest boarding school with thousands of students who come from various regions of North Sumatra and beyond. At this point, its alumni might play a significant role in developing Islam in North Sumatra. The second is

\footnotetext{
4 There has been an Islamic State in Sumatra namely Peureulak which is the center of the Islamic dakwah in the port of North Sumatra. Read M. A Karim, Islam Nusantara: Pengarub keislaman dalam Sejarah Bangsa Indonesia (Yogyakarta: Gama Media, 2007), 29-31; and M. Khairil Anwar and Muhammad Afdillah, "Peran Ulama di Nusantara dalam Mewujudkan Harmonisasi Umat Beragam," in Fikrab: Jurnal Ilmu Aqidah dan Studi Keagamaan, Vol. 4, No. 1 (2016).

5 See for example Islam Nusantara: Sejarah Sosial Intelektual Islam di Indonesia which does not consider North Sumatera not only in the context of region, but also in intellectual discourse.

${ }^{6}$ The account of Islam in Barus were cited by Musyrifah from JC van Leur.

7 Azyumardi Azra, "Sekapur Sirih" in Jaringan Global dan Lokal Islam Nusantara (Bandung, Mizan, 2002), 13. See also, Nurdinah Muhammad, "Karakteristik Jaringan Ulama Nusantara menurut Pemikiran Azyumardi Azra," in Jurnal Substantia, Vol. 14, No. 1 (April 2012).
} 
Madrasa or Maktab Tapanuli in Medan. This madrasa has a very important position especially for the development of Islam in East Sumatra. Maktab Tapanuli has become a meeting place of ulama that eventually gave birth to the largest organization in North Sumatra, namely Maktab al-Jam'iyyatul Washliyyah. From this maktab, many great scholars emerged and showed their important role in North Sumatra and the surrounding. Interestingly, Maktab Tapanuli, as its organic name, was established by the people from South Tapanuli who concern with Islamic education in Tanah Deli.

We will take these two Islamic centers as a focus in analyzing the dynamics of Islam in North Sumatra. We see that the development of Islam in this area has different patterns compared to other places. The network of ulama in North Sumatra in particular has its significant role in developing Muslim experiences with its uniqueness and characteristics. We wish to recognize their experiences as valid knowledge and a point of departure in explaining how Islam in North Sumatra come into being and develop up to this day.

Previous studies on the network of ulama in the development of Islam in North Sumatra has focused on the figure of ulama and Muslim experiences in a certain place. Muhammad Alpan Daulay, for example, studied the history of Sheikh H. Abdul Halim Hasan in developing Islam in the City of Binjai around 1927-1969. ${ }^{8}$ Similarly, Yushar Tanjung examined the emergence of Islam in Binjai and the process of its development. ${ }^{9}$ Both Daulay and Tanjung emphasized the figure-centered biographical analysis in explaining the ontological status of Islam in North Sumatra. While it may help to explain the power relation between the charismatic figure and the society, as well as showing the significance of Islamic figures in the process of Islamization, yet it may potentially reduce other influences and dynamics to a larger extent.

We feel that it is insufficient to explain the history of Islam in North Sumatra base on such a figure-centered analysis since it could simplify the complexity and dynamics in the process. It is important to see the wider perspective of how the Islamization process takes

\footnotetext{
8 Muhammad Alpan Daulay et. al, "Peranan Syekh H. Abdul Halim Hasan dalam Pengembangan Pendidikan Islam di Kota Binjai Pada Tahun 1927 - 1969," Edu Riligia, Vol 2, No 4, Oktober-Desember, (2018), 558-574.

9 Yushar Tanjung, "Jejak Islam di Kota Binjai, Sumatera Utara," Mukadimah, Vol 2, No 1, (2018), 73-83.
} 
place in North Sumatra through the network of ulama, and see how the connections may influence each other. Thus, our central questions are: (1) how does the network of ulama in North Sumatra build an Islamic understanding and how does this network relates to their teachers in the Middle East; (2) what are the roles of Mustafawiyah Boarding School and Maktab Islamiyah Tapanuli (MIT) in developing Islam in North Sumatra; (3) how does the role of the ulama in responding the social change in North Sumatra.

This study aims to examine the communication between fellow scholars in developing Islamic understanding in North Sumatra. It will also look at the role of educational institutions in the development of Islam, and the influence of ulama in calling social changes to the people of North Sumatra.

\section{Research Method}

This research is based on empirical evidence of Muslim societies in North Sumatra. By employing a descriptive qualitative method, this article aims to understand social problems, events, as well as the role of interaction and community groups. The qualitative approach is used by focusing on the social conditions surrounding the existence of the ulama who lived in the place, which became the basis in compiling the historical events of the ulama network in the development of Islam in North Sumatra in the $20^{\text {th }}$ century. Both written and oral data as a source of information conducted through in-depth interviews with informants, document studies, and field observations. The collected data is analyzed and presented in the form of a description. Qualitative data analysis is done interactively from discussion to a conclusion.

\section{The Role of Musthafawiyah Boarding School in the Development of Islam in North Sumatra}

Educational institutions in Indonesia is one of many aspects that play an important role in establishing, maintaining, and developing Islam. From traditional to modern science, the transmission and transformation of Islamic science cannot be separated from educational institutions. In the context of Islam in North Sumatra, we find that Musthafawiyah has been involved in the process of Islamization since its inception until today. 
Musthafawiyah Boarding School ${ }^{10}$ was founded by Sheikh Mustafa Hussein in 1912. ${ }^{11}$ Initially, this school established in the form of religious teaching called halaqah which was pioneered and nurtured by Sheikh Mustafa Hussein himself at a mosque in Tanobato Village, Mandailing. Later, the halaqah moved to Purba Baru Village because Tanabato was hit by flooding. Before the coming of Sheikh Mustafa Hussein, some scholars have been guarding the existence of Islam in Mandailing. However, as it will be demonstrated by the following description, the name of Sheikh Mustafa Hussein and Musthafawiyah is the culmination of the Islamic presence in Mandailing. From this school, Islam continues to evolve and develop into broader areas in Sumatra and its surrounding.

Sheikh Mustafa Hussein has his ability and method in developing the understanding of Islam in society. He was known for his moderation approach in introducing Islam to the communities. This makes his teaching of Islam can be easily understood and accepted. He teaches laypeople by using simple language and giving some examples. For the educated middle class, he communicates with religious language and systematic logic. It is because of his deep background of Islamic scholarship with a variety of religious literature enriched by the experience and social relationship that makes him welcomed by society.

Sheikh Mustafa Hussein is a charismatic figure and scholar. He is known as an independence and self-confidence figure. He did not have a dependency on and attachment to others. He has lifted again

10 The source elaborated in this research received from Umar Bakri through interview on December 29 2011 at his house, Banjar Guru. Besides, we also collected document of H. Burhanuddin et. Al, Riwayat Hidup Sheikh Mustafa Husein Purba Baru. Another source such as an article Sejarah Singkat Pesantren Mustafawiyah Purba Baru written by Amir Husein Lubis. Read also, Manshuruddin, "Corak Keagamaan Pesantren Salafiyah Musthafawiyah Purba Baru Mandailing Natal," in Al-Hadi, Vol. IV, No. 1 (July-December, 2018).

11 Sheikh Musthafa Husein (Muhammad Yatim) was the third son from 9 siblings. His father is H. Husein and his mother is Halimah. He was born at Tano Bato in 1303 Hijriyah (1886 M). He is a well known ulama in North Sumatra and left a famous Islamic building in Purba Baru, Mandailing. See Rusli Zainimal, "Biografi Syehk Musthafa Husein Nasution (Pendiri Pesantren Musthafawiyah Purba Baru) Di Mandailing Natal Sumatera Utara," paper was presented at Seminar Nasional Sejarah ke 4 Jurusan Pendidikan Sejarah Universitas Negeri Padang. Read also, Abbas Pulungan, "Pewarisan Intelektual dan Kharisma Kepemimpinan Di Pondok Pesantren Musthafawiyah Purba Baru Mandailing." In Jurnal Penelitian Pendidikan Agama dan Keagamaan, Vol. 3, No. 4 (October-December, 2005). 
the position of other scholars in the community. The scholars always dialogue and consult with him about Islam and society. ${ }^{12} \mathrm{He}$ also has a network with all levels of societies such as farmers, traders, government officials, social and religious organizations, as well as with the great scholars in a variety of areas, including Java.

The alumni of Musthafawiyah takes part in serving and educating the surrounding communities. Most of them become a religious leader in their village, initiating, and performing various religious activities. On the other hand, some alumni continue their studies to Mecca. These alumni built another boarding school in their villages after they finished their studies in Mecca. While others come back to Musthafawiyah and become a teacher. Sheikh Abdul Halim Khatib is one of the alumni that becomes the right hand of Sheikh Mustafa Hussein in Musthafawiyah Boarding School. Some join a religious organization like MUI. Musthafawiyah itself has its own Fatwa Council. ${ }^{13}$

Besides establishing Musthafawiyah, Sheikh Mustafa Hussein also initiated the establishment of Nahdlatul Ulama in North Sumatra. Through his network of alumni of the Middle East in Java, he takes Nahdlatul Ulama to North Sumatra. This is why most of the members of Nahdhatul Ulama in North Sumatra are generally dominated by alumni of Musthafawiyah. They make NU spread and develop to other regions such as South Tapanuli, Center Tapanuli, Labuhan Batu, and Regional Malay. ${ }^{14}$ Students of Musthafawiyah are enthusiastic about organizing NU because they considered NU as dakwah and symbol of Islam. They have a genuine and sincere intention to develop and serves NU as a part of the enforcement of sharia.

12 Including the influence of Sheikh Mustafa Hussein in Purba Baru Village. See Purnama Lubis, "Kontribusi Pemikiran Syekh Musthafa Husein terhadap Teologi Masyarakat Purba Baru Kecamatan Lembah Sorik Marapi," in Al-Lubb, Vol. 2, No. 1 (2017).

13 When this research was done, Majelis Fatwa Mustafawiyah was conducted by $\mathrm{H}$. Abdi Batubara and also as Rais al-Mu'allimin Pondok Pesantren Mustafawiyah Purba Baru.

14 Mahmuddin Pasaribu, "Guru Senior Pesantren Musthafawiyah," Waspada, Thursday, 22 March, 2012. 


\section{The Role of Maktab Islamiyah Tapanuli (MIT) In Developing Islam in North Sumatra}

In 1918, the Mandailing community which settled in Medan has the initiative to build an Islamic education called Maktab Islamiyah Tapanuli (MIT). They are immigrants from South Tapanuli which adjacent to the land of Minangkabau, West Sumatra. Mandailings are well known as a strong and educated Muslim community compared to other ethnic groups. While MIT as an institution is well known for two respects; first, it is the first formal Islamic education institutions; and secondly, the establishment of Al-Jam'iyatul Washliyah is the brainchild of the maktab alumni. ${ }^{15}$

The appearance of Islamic education in Medan does not emerge out of the blue. There is a long process that goes hand in hand with the development of Medan. Before the existence of Maktab Islamiyah Tapanuli, the process of Islamic teaching and learning has been done at the mosque and at home. ${ }^{16}$ Many experts said that MIT is not only the first Islamic educational institution, but it is also the first modern educational institution in Medan. Interestingly, MIT was founded by leaders who came from South Tapanuli and not from Medan itself. ${ }^{17}$

There is no significant clue concerning who is the initiator of MIT. However, Sheikh H. Moehammad Yacoeb is believed to be the founder of his notes entitled Catatanku to explain the story of MIT. Another important figure is Sheikh Ja'far Hasan and Sheikh Mahmud Jonah who also contribute to the establishment of MIT and its influences in the context of the dynamics of Islamic intellectualism in Medan and North Sumatra. Jonah was born in Kampong Roburan Mandailing in 1880. As a child, he studied religion with his parents. Towards a teenager, he migrated to Deli and lived with his uncle, a wealthy merchant named H. Hamid, who opened shop in Kesawan Batik.

\footnotetext{
15 Hasan Asari, Modernisasi Islam, Tokoh, Gagasan dan Gerakan (Bandung: Cita Pustaka Media, 2002), 234-235. Dja'far Siddik and Rosnita, "Gerakan Pendidikan AlWashliyah Di Sumatera Utara," in Ulumuna Jurnal Studi Keislaman, Vol. 18 No. 1 June 2014).

16 Karel A. Steenbrink, Pesantren Madrasab Sekolah: Pendidikan Islam dalam Kurun Modern (Jakarta: LP3ES, 1991), 10.

17 Muaz Tanjung, Pendidikan Islam di Medan pada Awal Abad ke-20, (Medan: tesis di IAIN Sumatera Utara, 2004), 15.
} 
Similar to Mushtafawiyah, the alumni of MIT also play an important role in developing an Islamic institution in Medan. In 1928, students from the higher grade namely A. Rahman Shihab, Kular, Ismail Banda, Adnan Nur, and H. Solomon created a study group called "Debating Club." This study group later developed into a higher institution called Al-Jam'iyyatul Washliyah. Sheikh H. Muhammad Yunus is the person who gives the name of this institution. He was born in Binjai in 1889 and is the son of $\mathrm{H}$. Muhammad Arsyad.

Besides those who created Al-Jam'iyyatul Washliyah, other alumni of MIT become great scholars who continue their works in the development of Islam in North Sumatra. The most notable names are H. Adnan Lubis, H.M. Yusuf Ahmad Lubis, H. Anas Cape, Sheikh Abdur Azra'i Ra'uf, H. Ahmad Burhanuddin, K H. Abdul Aziz, Husein Abdul H. Karim, H. Mahmud Darbaini, H. Ahmad Badal, H. Abu Bakar Ya'cub, and H. Mukhtar A. Rahim, H. Bahrum Ahmad, Aziz Usman H, and H. Baharuddin Shah.

In the development of these two major institutions, AlJam'iyyatul Washliyah is the only institution that is functioning up to this day. While MIT was forced to close their institution due to unfavorable political situation. Interestingly, the building of MIT is now being loaned to Al-jam'iyyatul Washliyah. It is worth noting that Al-Jam'iyatul Washliyah has created many great scholars and leaders who have been acting in various areas in Indonesia.

\section{The Relationship of North Sumatra and the Middle East in the $20^{\text {th }}$ Century}

According to Azyumardi Azra, many Indonesian stayed in the Middle East, especially Mecca and Medina, since the $15^{\text {th }}$ Century. They are called as Ashab Al-jawin. In this situation, the ulama from Indonesia has successfully established a solid network with the ulama in the Middle East between the $17^{\text {th }}$ Century and $18^{\text {th }}$ Centuries. There are good relationships between students and teachers which are caused by two factors; a matter of isnäd hadith and genealogy of tarekat (sufi order). Azra argues that both of these two factors have a crucial role in connecting scholars involved in the network which is based in Haramayn in the $18^{\text {th }}$ Century. ${ }^{18}$

18 Azra, Jaringan Ulama, 105. 
Around the $15^{\text {th }}$ Century, Muslims and ulama from Indonesia have visited the holy land (Mecca) in the context of hajj or studying. The presence of ulama in Haramayn with their significant movement and role has reformed and developed Islamic thought in Indonesia between the $17^{\text {th }}$ to $18^{\text {th }}$ Centuries. According to Azra, three ulama have an important role in the intellectual network in Indonesia. They are Sheikh Nur Al-Din Al-Raniri (w.1068/1658), 'Abd Al-Ra'uf AlSinkili (1024-1105/1615-930), and Muhammad Yusuf Al-Makassari (1037-1111/1627-99).

There is no exact data regarding who is the first person from Indonesia that goes to Mecca for the pilgrimage and hajj. However, throughout our study, there is one name that is often mentioned by the people of North Sumatra. He is Sheikh 'Abd Al-Qadir AlMandy. ${ }^{19}$ In the context of this study, some of the ulama who had ever studied to Sheikh Abdul Qadir Al-Mandily were Sheikh Mustafa Hussein (1900), Sheikh Hasan Ja'far in (1904), Sheikh Mohammad Yunus, ${ }^{20}$ and Sheikh Hasan Maksum.

Some well-known ulama that have been mentioned above indicated how strong the influence of Sheikh Abdul Qadir Al-Mandily in the network of Islamic intellectualism in North Sumatra. Unfortunately, among the information that we have collected, we do not find any works written by him. Apart from that, we want to show that the network of Middle East theologian in North Sumatra has its dynamics. Some data showed that a network of ulama in North Sumatra centered on Sheikh Abdul Qadir Al-Mandily. ${ }^{21}$

\section{The Network of Ulama in North Sumatra}

In this section, we examined the role of Maktab Islamiyah Tapanuli (MIT) and Musthafawiyah. There are three important points that we think these institutions are important to the development of Islam in North Sumatra. First, both MIT and Musthafawiyah has a historical account of educational institutions that created many great ulama across North Sumatra and beyond. Second, the ulama that was born from both institutions has the same network in the Middle East.

19 MUI Sumatera Utara, Sejarah Ulama-Ulama Terkemuka di Sumatera Utara (Medan: Institut Agama Islam Negeri, 1983), 209.

${ }^{20}$ In Some data that we examined, there is some document that did not mention the name of Sheikh Muhammad Yunus.

21 Jajat Burhanuddin, Ulama dan Kekuasaan: Pergumulan Elit Muslim dalam Sejarah Indonesia (Bandung: Mizan, 2012), 122-127. 
Third, the teaching concept which is developed by both institutions has been transformed by their alumni into a form of organization, namely Al-Washliyah and Nahdlatul Ulama of North Sumatra. All of these points will be elaborated in the following discussion.

First, MIT and Mushtafawiyah were the first Islamic institution that exists in Medan and gave birth to many great ulama. They play important roles in spreading Islam to North Sumatra. If we see the great names of some ulama in North Sumatra at the beginning of the $21^{\text {st }}$ Century, most of them have an attachment to both institutions. The names such as Sheikh Jafar Hasan, Sheikh Mohammad Yunus, Isma'il Banda, Abdurrahman Shihab, Udin Shamsuddin were the founder and primary students of MIT. Likewise, Sheikh Hasan Maksum was an advisor of Al-Washliyah. Some of his students become prominent scholars in North Sumatra such as Al-Ustadz Arsyad Lubis Talib and Al-Ustadz Zainal Arifin Abbas.

The progress of Mushtafawwiyah in developing Islam in North Sumatra has a significant meaning, especially to the West Sumatra. Since the end of Padri War in West Sumatra, the development of Islam was taken by the ulama from Mandailing itself, regardless of the controversial issues. Some of the names that play an important role at the time until the coming of Sheikh Mustafa Hussein was Sheikh Sulaiman Al-Khalidy, who was born in Huta Pungkut. In the place of his birth, he had developed Islamic teaching as well as an established Islamic congregation. He also built the place of persulukan near his house. According to Abbas Pulungan, his students scattered around Mandailing such as Muara Sipongi, Sibuhuan, Padang Lawas, and around Padang Sidempuan or Angkola-Sipirok. ${ }^{22}$

Sheikh Abdul Hamid was also born in Hutapungkut, Kotanopan, in 1859. He inspired the emergence of many great ulama such as Sheikh Mustafa Hussein and Sheikh Muhammad Fauzi. While Sheikh Sulaiman Al-Khalidy developed Sufi order (tariqat), Sheikh Muhammad Fauzi focused on the development of Islamic jurisprudence (fiqh). Despite Sheikh Mustafa Hussein and others developed Islam in Mandailing after the second era of the scholars, however, the Islamic color of Musthafawiyah is still very obvious. It is because of the role of their very extensive students.

22 Abbas Pulungan, Perkembangan Islam di Mandailing (Bandung: Cita Pustaka, 2008), 97-98. 
Strategically, there are similarities between MIT and Musthafawiyah in developing Islam. Apart from conventional da'wah, they also use educational institutions. It seems that education is the most effective way in that era. Although the struggle of MIT has stopped after the Japanese aggression in Tanah Deli, yet the spirit of MIT remains alive. There was a study club named "debating club" which eventually became the embryo of the establishment of AlWashliyah. This institution that later developed the spirit of MIT in spreading Islam.

There is an assumption that the founder of MIT, Sheikh Hasan Ja'far, and the founder of Musthafawiyah, Sheikh Mustafa Hussein, were students of Sheikh Abdul Qadir Al-Mandily. Unfortunately, there is no accurate information and data regarding this issue. However, when we analyze a simple data such as date of birth and year of their departure to Mecca, most of these two leaders were met in the majlis of Sheikh Abdul Qadir Al-Mandily. Syekh Hasan Ja'far (1880-1950) went to study in Mecca in 1904 and came back in 1912. While Sheikh Mustafa Hussein (1886-1937) went to Mecca in 1900 and came back in the same year of 1912. Both of them stayed for around 12 years in Mecca. We think that there is a possibility that they met each other at that time.

Another scholar or ulama, Sheikh H. M. Yunus (1889-1960) perceived to meet with Sheikh Hasan Ja'far since both of them have a significant contribution to MIT. However, there is no information that Sheikh H. M. Yunus communicated intensively with Sheikh Mustafa Hussein, despite both of them have met in a various majlis. He also went to Mecca like the other two scholars, yet there is no indication that he studied under Sheikh Abdul Qadir Al-Mandily. According to the history book issued by MUI, the only teacher of Sheikh H. M. Yunus was Sheikh Abdul Muttalib who lived in Titi Gantung, Binjai.

Another interesting story is the network of Sheikh Hasan Maksum (1884-1937). He was four years younger than Sheikh Ja'far Hasan and two years older than Sheikh Mustafa Hussein. He is also one of the ulama who had lived in Mecca since he was 10 years old in 1895. He came back to Deli in 1903. At that time, Sheikh Ja'far Hasan was still in Medan and Sheikh Mustafa Hussein had gone to Mecca three years before the return of Sheikh Hasan Maksum. After that, Sheikh Hasan came back to Mecca and returned to Deli in 1916. 
There were assumptions that they met in Mecca, yet there is no clear data about it.

For the following developments, these figures met in the organization of Al-Jam'iyyatul Washliyah. During the initial formation of this organization, Sheikh Hasan Maksum and Sheikh H. M. Yunus became advisors at Al-Washliyah. It was Sheikh H. M. Yunus who gave the name of the organization. While Sheikh Mustafa Hussein founded Nahdlatul Ulama (NU) in Mandailing, South Tapanuli.

Regarding the concept of Islam developed by these figures, there is a conflict of ideas between "the old" and "the young" generation. "The young" are originally Minang people who migrated to Medan and brought Muhammadiyah to the place. Initially, the presence of Al-Jam'iatul Washliyah serves as a bridge within the framework of different ideologies. However, they eventually emerge as a new ideology that much different from Muhammadiyah.

According to Usman Pelly, although Mandailing and Minangkabau are neighbors, there is a difference between these two cultures. Minangkabau ethnics are predominantly modernist Muslims who have a strong matrilineal tradition, especially in terms of succession, inheritance, identity, and legitimacy. While the majority of Mandailaings are popularly known as conservative Muslims who have a strong patrilineal tradition in terms of succession, inheritance, identity, and legitimacy. The latter are more likely to perform territorial expansion. ${ }^{23}$

Thus, Minangkabau people tend to align with Muhammadiyah, while the Mandailings - except for certain region such as Sipiroktends to adhere to the old school of Shäfi'iyyah. ${ }^{24}$ In the end, after the formation of Al-Jam'iyatul Washliyah, most people choose to follow this organization. Hasanuddin ${ }^{25}$ illustrated quite clearly that the figures who take charge of Al-Washliyah during the first period are generally the Mandailings, such as $\mathrm{H}$. Ilyas (Mandailings), Ismail Banda (Mandailings), H. Mahmud (qadi) (Mandailings), Adnan Nur (Mandailings), H. M. Ya'cub (Mandailings), Abdurrahman Shihab (Mandailings), Sheikh Hasan (Malay) and Sheikh M. Yunus (Mandailaings).

23 Usman Pelly, Urbanisasi dan Adaptasi: Peranan Misi Budaya Minangkabau dan Mandailing (Jakarta: LP3ES, 1991), 6.

${ }^{24}$ Karel A. Steenbrink, Pesantren, Madrasah, Sekolah, 76-77.

25 Usman Pelly, Urbanisasi dan Adaptasi: Peranan Misi Budaya Minangkabau dan Mandailing (Jakarta: LP3ES, 1991). 
It is not surprising that initially, Mandailings have a harmonious relationship with the Sultan Deli and Malay people. The reason is that the Mandailings are known for their obedience to religion. They have the same characteristic as what is practiced by the empire of Deli at the time. The Sultan and the Malay community perceived them to be different from the Minangkabau due to the organization and their respective ideologies. On this basis, in the early days of its formation, Al-Washliyah seemed to find its momentum to rise and participate in the development of Islam in North Sumatra.

In the book of Al-Jam'iyatul Washliyah, there is a brief biography of Sheikh Mustafa Hussein. In Padang Sidempuan 1933, there was Muslim Tapanuli Unity where he was appointed as an advisor. In 1936 at the Congress of Al-Washliyah, he was appointed as an advisor of Al-Washliyah. In 1939, he initiated the Association of AlIttihadiyatul Islamiyah (AII) in Purba Baru, based on the principle of society and led by many madrasas in Tapanuli. In February 1947, he also initiated a meeting for all of the theologian and Islamic leaders at Tapanuli, housed in Padang Sidempuan. This meeting leads to the establishment of NU in Tapanuli and in which it eventually became NU in North Sumatra.

It is interesting to see why Sheikh Mustafa Hussein established NU in South Tapanuli and not in other areas. Of course, many factors may involve such as political issues and cultural mission. However, apart from that, we think that the movement of AlWashliyah into NU has no significant barriers both ideologically and psychologically. The willingness of Sheikh Mustafa Hussein to be an advisor of Al-Washliyah shows how a network of scholars at the time was quite well. They have the awareness that the development of Islam in North Sumatra can be done in many ways. It can be through conventional propaganda, educational institutions, and Islamic organization.

\section{The Response of Ulama and the Social Change}

In this section, we would like to revisit Mohammad Natsir's article entitled, Status of Ulama2 In Masjarakat banner of Islam published in the edition of June 1939 and reissued in collective writing entitled Capita Selecta by Mohammad Natsir, et al:

“...masjarakat Islam sudah mempunjai pemimpin dan penganjur mereka dalam hal-hal jang berhubungan dengan keagamaan dan penghidupan mereka sehari-hari. Dalam desa- 
desa dan kampung-kampung Guru atau Sjech, Angku Sieh di Minangkabau atau Kiai di Djawa dan bermatjam2 nama panggilan pada beberapa tempat, adalah tempat rakjat bertanja, tempat memulangkan sesuatu urusan, tempat meminta nasihat dan fatwa, tempat mereka menaruhkan kepertjajaan.

Bagi mereka, fatwa seorang alim jang mereka pertjajai berarti suatu kata-keputusan, jang tdak dapat dan tak perlu disbanding lagi. Seringkali terbukti, bagaimana susahnja bagi pemerintah negeri mendjalankan satu urusan, bilamana tidak disetudjui oleh alim-ulama jang ada dalam satu daerah.

Sebaliknjapun begitu pula. Beruntunglah salah satu masjarakat, bila mempunjai seorang alim, sebagai pemimpin ruhani jang tahu dan insaf akan tanggungannja sebagai penganjur dan penundjuk djalan. Aman dan makmurlah salah satu daerah bilamana pegawai-pegawai pemerintah di situ tahu menghargakan kedudukan alim ulama ang ada di daerah itu.

Ulama bukanlah pemimpin yang dipilih dengan suara terbanjak, bukan jang diangkat oleh persidangan kongres. Akan tetapi kedudukan mereka dalam kebatinan rakjat yang mereka pimpin, djauh lebih teguh dan tjuci dari pergerakan jang berorganisasi, atau pegawai pemerintah jang manapun djuga.

Ulama ialah waris nabi-nabi, pemimpin umat jang mendapat pengakuan agama. Dalam mentjapai kemadjuan rakjat umumnja, "korsp" ulama jang bertebaran itu sekali-kali tak boleh diabaikan, baik oleh pegawai pemerintah, ataupun oleh pengandjur-pengandjur pergerakan kita. Mereka itu adalah satu faktor jang penting dalam kerdja pertjerdasan rakjat pada umumnja. Koordinasi pekerdjaan antara ulama-ulama, pegawai-pegawai pemerintah dan pemuka-pemuka pergerakan sosial dan politik, tidak akan diperdapatm bilamana pihak ulama tidak berkehendak turut memperhatikan dan menurutkan gelora zaman,..."26

The quotation above shows the importance of the position of ulama both to the government and society. At this point, scholars should be able to position themselves appropriately. They also have to face the challenge of social change that always evolves through times.

In North Sumatra, the ulama has shown their significant roles in the construction of the community. The theologian, for example, has the responsibility to manage Muslims in terms of faith, sharia, and characters. They took not only traditional sermon or halaqah, such as

${ }^{26}$ Mohammad Natsir, Capita Selecta (Jakarta: Bulan Bintang, 1955), 133-138. 
the prosecution of science at Al-Haram, but also responses to the development of modernization. It can be seen through how they adopted modern educational models and apply them to the system of Islamic education.

Change is inevitable whether they would open to social change or not. If we look at history, the theologian has an awareness of struggle and change. The emergence of the discussion club in the form of "debating club" eventually leads to the birth of Al-Jam'iyatul Washliyah. It shows that the young generation at the time was sensitive to discuss the issues of Muslim and social life. They seem to have an awareness of the development of the community in terms of social and religious issues. They think that there is a need for the organization as a means of struggle in developing Islamic understanding in the place. The establishment of NU and AlWashliyah is the evidence of their effort and struggle in developing Islam and society.

\section{Conclusion}

The role of the ulama network in the development of Islam in North Sumatera in the $20^{\text {th }}$ century cannot be separated from the presence of Maktab Islamiyah Tapanuli and Musthafawiyah. There are three important points concerning the development of Islam in North Sumatra as a result of these two organizations. First, both MIT and Musthafawiyah has a historical account of educational institutions that created many great ulama across North Sumatra and beyond. Second, the ulama that was born from both institutions has the same network in the Middle East. Third, the teaching concept which is developed by both institutions has been transformed by their alumni into a form of organization, namely Al-Washliyah and Nahdlatul Ulama of North Sumatra.

\section{References}

Abidin, A. Z. "Sejarah Masuk dan Berkembangnya Islam Di Sumatera," in Muhammad Dalil and Abdullah Syah, Sejarah Da'wah Islamiyah dan Perkembangannya di Sumatera Utara. Medan: MUI Sumatera Utara, 1983.

Amin, F. and Rifki A. A. "Kedatangan dan Penyebaran Islam di Asia Tenggara Tela'ah Teoritik tentang Proses Islamisasi Nusantara," in Jurnal Analisis: Jurnal Studi Keislaman, Vol. 18, No. 2, (2018). 
Anwar, M. K. and Muhammad Afdillah. "Peran Ulama di Nusantara dalam Mewujudkan Harmonisasi Umat Beragama," in Fikrah: Jurnal Ilmu Aqidah dan Studi Keagamaan, Vol. 4, No. 1, (2016).

Asari, H. Modernisasi Islam, Tokoh, Gagasan dan Gerakan. Bandung: Cita Pustaka Media, 2002.

Azra, A. "Sekapur Sirih" in, Jaringan Global dan Lokal Islam Nusantara. Bandung: Mizan, 2002.

----. Historiografi Islam Kontemporer, Wacana, Aktualitas dan Aktor Sejarah, Idris Thaha (Ed). Jakarta: Gramedia, 2002.

-----. Islam Nusantara: Jaringan Global dan Lokal, Bandung: Mizan, 2002.

-----. Jaringan Ulama Timur Tengah dan Kepulanan Nusantara Abad XVII dan XVIII: Melacak Akar-akar Pembaruan Pemikiran Islam di Indonesia: Bandung: Mizan, 1994.

Benda, H. J. Bulan Sabit dan Matahari Terbit. Jakarta: Pustaka Jaya, 1980. Burhanuddin, J. Ulama dan Kekuasaan: Pergumulan Elit Muslim dalam Sejarah Indonesia. Bandung: Mizan, 2012.

Castles, L. Kehidupan Politike Suatu Keresidenan di Sumatra: Tapanuli 19151940. Jakarta: Gramedia, t.th.

Daulay, Muhammad Alpan, et. al. "Peranan Syekh H. Abdul Halim Hasan dalam Pengembangan Pendidikan Islam di Kota Binjai Pada Tahun 1927 - 1969." Edu Riligia, Vol 2, No 4, OktoberDesember, (2018).

Fiderspiel, H. M. Persatuan Islam, Pembaharuan Islam Indonesia Abad XIX. Yogyakarta: Gadjah Mada University Press, 1996.

Geertz, C. Abangan, Santri dan Priyayi dalam Masyarakat Jawa. Jakarta: Pustaka Jaya, 1981.

Horikoshi, H. Kyai dan Perubahan Sosial (A Traditional Leader in a Time of Change: The Kijaji and Ulama in West Java. Jakarta: P3M, 1987.

Jay, R. Santri, Abangan, Religious Schism in Rural Java. Harvard: Harvard University, 1957.

Karim, M. A. Islam Nusantara: Pengaruh keislaman dalam Sejarah Bangsa Indonesia. Yogyakarta: Gama Media, 2007.

Lubis, P. "Kontribusi Pemikiran Syekh Musthafa Husein terhadap Teologi Masyarakat Purba Baru Kecamatan Lembah Sorik Marapi," in Al-Lubb, Vol. 2, No. 1, (2017).

Manshuruddin. "Corak Keagamaan Pesantren Salafiyah Musthafawiyah Purba Baru Mandailing Natal," in Al-Hadi, Vol. IV, No. 1, (2018). 
Muhammad, N. "Karakteristik Jaringan Ulama Nusantara menurut Pemikiran Azyumardi Azra," in Jurnal Substantia, Vol. 14, No. 1, (2012).

MUI Sumatera Utara. Sejarah Ulama-ulama Terkemuka di Sumatera Utara.

Medan: Institut Agama Islam Negeri Sumatera Utara, 1983.

Natsir, M. Capita Selecta. Jakarta: Bulan Bintang, 1955.

Siddik, D. and Rosnita. "Gerakan Pendidikan Al-Washliyah Di Sumatera Utara," in Ulumuna Jumal Studi Keislaman, Vol. 18 No. 1, (2014).

Steenbrink, K. A. Pesantren Madrasah Sekolah: Pendidikan Islam dalam Kurun Moderen, cet. 2. Jakarta: LP3ES, 1991.

Tanjung, Yushar. "Jejak Islam di Kota Binjai, Sumatera Utara." Mukadimah, Vol 2, No 1, (2018).

Tanjung, M. "Pendidikan Islam di Medan Pada Awal Abad ke 20." Medan: tesis di IAIN Sumatera Utara, 2004.

Pelly, U. Urbanisasi dan Adaptasi: Peranan Misi Budaya Minangkabau dan Mandailing. Jakarta: LP3ES, 1994.

Pulungan, A. Perkembangan Islam di Mandailing. Bandung: Cita Pustaka, 2008.

-----. "Pewarisan Intelektual dan Kharisma Kepemimpinan di Pondok Pesantren Musthafawiyah Purba Baru Mandailing." In Jurnal Penelitian Pendidikan Agama dan Keagamaan, Vol. 3, No. 4, (2005).

Wertheim, W. F. Indonesia Society in Transition. Bandung: Sumur, 1956.

Zainimal, R. "Biografi Syekh Musthafa Husein Nasution (Pendiri Pesantren Musthafawiyah Purba Baru) di Mandailing Natal Sumatera Utara," a paper presented at Seminar Nasional Sejarah ke-4 Jurusan Pendidikan Sejarah Universitas Negeri Padang. 